\title{
Wastewater Treatment in Musaliar College
}

\author{
Leena V P ${ }^{1}$, Alan P Thomas ${ }^{2}$, Hashim Ansari ${ }^{3}$, Joseph Reji ${ }^{4}$, Muhamad Naif S S \\ ${ }^{1}$ Associate Professor, \\ ${ }^{2345}$ Student \\ Civil Department, Musaliar College of Engineering \& Technology, \\ Pathanamthitta.
}

\begin{abstract}
The area of our project is the planning and designing of waste water treatment plant in Musaliar College of Engineering and Technology, Pathanamthitta. There is a lot of water is wasted in the college campus. During summer season availability of fresh water is less. The main objective of this project is to reduce the demand of potable water and generate the new source from reuse of waste water. Waste water treatment process is designed to achieve improvements in the quality of waste water. Waste water treatment is closely related to the standards and expectations set for the effluent quality. The campus requires a huge amount of water for different purposes like cleaning, gardening etc. So to fulfill the demand of water we work on treatment and reuse of waste water generated in college departments and hostel. Thus it reduces the load over fresh water and to reduce the demand of fresh water, treatment is required for wastewater and then it is utilized.
\end{abstract}

Key words: Waste water, Treatment, Reuse, Chemical parameters.

\section{INTRODUCTION}

The study at Musaliar College focuses on the planning of a new water source. The campus lacks water source inside the compound. Large amount of water is needed for the daily use. During summer season, the availability of fresh water is very less. In order to overcome the situation a new method is proposed. This is by treating the waste water from the wash basins, cooler. In hostel the water after washing the clothes is also used for the treatment. By treating this water a new source is generated and this water can be used for washing, gardening except for drinking purpose.

\section{OBJECTIVES}

- To reduce demand of potable water.

- To generate a new source from reuse of wastewater.

- It is the major element of water pollution control.

- To decrease the scarcity of water and increase the water supply.

- $\quad$ More efficient resource management.

- To provide cost saving method.

- To provide a better sustainable method.

- $\quad$ To minimize the waste.

\section{SCOPE}

To conduct necessary studies regarding the planning of a new waste water treatment method and thereby reducing the problem of water scarcity. To determine the chemical and physical characteristics of the water. This method improves the overall efficiency and method used here is cost effective. Estimation is also calculated for analysing the cost.

\section{METHODOLOGY}

Data Required:

1. Quantity of waste water generated in college departments and hostel from wash basins, bathrooms.

2. Total number of students and staffs in each department and also for hostel total students in the hostel is calculated

3. Characteristics of water.

4. Indian Standards of irrigation water.

\section{Methodology:}

In this first the waste water is analysed and the chemical characteristics of the water is tested. Next is the selection of the treatment method. Then the filter media is selected and the design of the filter media is carried out. Then the treated water is again tested. Finally the analysis of the treated water is carried out

\section{Analysis of waste water.}

In this the amount of waste water generated is calculated. For the calculation, the amount of water used in various department by each student for washing is taken as $1.51 /$ head/day and the water used by students in the Men's hostel for bathing is taken as 301/head/day. These are then multiplied with the number of people using per day gives the total quantity of waste water generated in each day.

2. $\quad$ Testing of the waste water from college and hostel. In this the chemical and physical characteristics of the water is calculated. Some parameters like BOD, COD, turbidity, chlorides, $\mathrm{pH}$ etc. are important in determining the water whether it can be used for any purpose.

\section{Selection of treatment.}

Preliminary treatment is done by passing it through the meshes. In domestic wastewater treatment, preliminary and primary processes will remove approximately 25 percent of the organic load and virtually all of the nonorganic solids. Then the water is passed through the filter media in the primary treatment. Finally it is passed to another tank for the secondary treatment. Secondary treatment is the biological treatment. Algae is used for the biological treatment. Components of the filter media:

\section{Activated charcoal}

It is the activated carbon which has high adsorption capacity. Due to its high degree of micro porosity, just one gram of activated carbon has a surface area in excess of $3000 \mathrm{~m}^{2}$ as 
determined by gas adsorption. Activated charcoal traps impurities in water including solvents, pesticides, chemicals etc.. Size selected is less than 75 micron.

\section{2. $\quad$ Sand}

Sand bed work by providing the particulate solids with many opportunities to be captured on the surface of the sand grain. These captures by surface charge repulsion mechanism. The sand of size $1 \mathrm{~mm}$ to $1.36 \mathrm{~mm}$ is used for this filter.

\section{RESULTS AND DISCUSSIONS}

Test results of the wastewater from various department and hostel are discussed below;

\section{Aggregate}

Filter gravel is used as a support media to filter sand. For maximum efficiency aggregate should be rounded than angular. Size is about $10 \mathrm{~mm}$ to $12.5 \mathrm{~mm}$.

TABLE 1 TEST RESULT OF WASTE WATER FROM VARIOUS DEPARTMENT BEFORE FILTERATION

\begin{tabular}{|c|c|c|c|}
\hline SI.NO & Parameters & Readings & Desirable limits \\
\hline 1 & Turbidity & 0.5 & $1 \mathrm{NTU}$ \\
\hline 2 & $\mathrm{pH}$ & 5.99 & 6.5 to 8.5 \\
\hline 3 & Acidity & 10 & \\
\hline 4 & Alkalinity & 24 & $200 \mathrm{mg} / \mathrm{l}$ \\
\hline 5 & Sulphate & 1.5 & $200 \mathrm{mg} / \mathrm{l}$ \\
\hline 6 & Total Dissolved Solids & 41 & $500 \mathrm{mg} / 1$ \\
\hline 7 & Total Hardness & 30 & $200 \mathrm{mg} / \mathrm{l}$ \\
\hline 8 & Calcium & 8 & $75 \mathrm{mg} / \mathrm{l}$ \\
\hline 9 & Magnesium & 2.43 & $30 \mathrm{mg} / \mathrm{l}$ \\
\hline 10 & Chloride & 10 & $250 \mathrm{mg} / 1$ \\
\hline 11 & Fluoride & 0.04 & $1 \mathrm{mg} / \mathrm{l}$ \\
\hline 12 & Nitrate & 5 & $45 \mathrm{mg} / \mathrm{l}$ \\
\hline 13 & Residual Chlorine & 0 & $0.2 \mathrm{mg} / \mathrm{l}$ \\
\hline
\end{tabular}

TABLE 2 TEST RESULT OF WASTE WATER FROM HOSTEL BEFORE FILTERATION

\begin{tabular}{|c|c|c|c|}
\hline SI.NO & Parameters & Readings & Desirable limits \\
\hline 1 & Turbidity & 0.8 & $1 \mathrm{NTU}$ \\
\hline 2 & $\mathrm{pH}$ & 4.66 & 6.5 to 8.5 \\
\hline 3 & Acidity & 16 & $200 \mathrm{mg} / 1$ \\
\hline 4 & Alkalinity & 32 & $200 \mathrm{mg} / 1$ \\
\hline 5 & Sulphate & 2.9 & $500 \mathrm{mg} / 1$ \\
\hline 6 & Total Dissolved Solids & 89 & $200 \mathrm{mg} / 1$ \\
\hline 7 & Total Hardness & 61 & $75 \mathrm{mg} / 1$ \\
\hline 8 & Calcium & 6 & $30 \mathrm{mg} / 1$ \\
\hline 9 & Magnesium & 1.3 & $250 \mathrm{mg} / 1$ \\
\hline 10 & Chloride & 48 & $1 \mathrm{mg} / 1$ \\
\hline 11 & Fluoride & 0.02 & $45 \mathrm{mg} / 1$ \\
\hline 12 & Nitrate & 2 & $0.2 \mathrm{mg} / 1$ \\
\hline 13 & Residual Chlorine & 0 & \\
\hline
\end{tabular}

TABLE 3 TEST RESULT OF WASTE WATER FROM VARIOUS DEPARTMENT AFTER FILTERATION

\begin{tabular}{|c|c|c|c|}
\hline SI.NO & Parameters & Readings & Desirable limits \\
\hline 1 & Turbidity & 0.33 & $1 \mathrm{NTU}$ \\
\hline 2 & $\mathrm{pH}$ & 5.8 & 6.5 to 8.5 \\
\hline 3 & Acidity & 12 & \\
\hline 4 & Alkalinity & 18.6 & $200 \mathrm{mg} / \mathrm{l}$ \\
\hline 5 & Sulphate & 1.9 & $200 \mathrm{mg} / \mathrm{l}$ \\
\hline 6 & Total Dissolved Solids & 32 & $500 \mathrm{mg} / \mathrm{l}$ \\
\hline 7 & Total Hardness & 47 & $200 \mathrm{mg} / \mathrm{l}$ \\
\hline 8 & Calcium & 4 & $75 \mathrm{mg} / \mathrm{l}$ \\
\hline 9 & Magnesium & 0.8 & $30 \mathrm{mg} / 1$ \\
\hline 10 & Chloride & 33 & $250 \mathrm{mg} / \mathrm{l}$ \\
\hline 11 & Fluoride & 0.01 & $1 \mathrm{mg} / \mathrm{l}$ \\
\hline 12 & Nitrate & 3 & $45 \mathrm{mg} / 1$ \\
\hline 13 & Residual Chlorine & 0 & $0.2 \mathrm{mg} / \mathrm{l}$ \\
\hline
\end{tabular}


TABLE 4 TEST RESULT OF WASTE WATER FROM HOSTEL AFTER FILTERATION

\begin{tabular}{|c|c|c|c|}
\hline SI.NO & Parameters & Readings & Desirable limits \\
\hline 1 & Turbidity & 0.9 & $1 \mathrm{NTU}$ \\
\hline 2 & $\mathrm{pH}$ & 7.8 & 6.5 to 8.5 \\
\hline 3 & Acidity & 8.5 & \\
\hline 4 & Alkalinity & 15.3 & $200 \mathrm{mg} / \mathrm{l}$ \\
\hline 5 & Sulphate & 2.6 & $200 \mathrm{mg} / \mathrm{l}$ \\
\hline 6 & Total Dissolved Solids & 12 & $500 \mathrm{mg} / \mathrm{l}$ \\
\hline 7 & Total Hardness & 21 & $200 \mathrm{mg} / 1$ \\
\hline 8 & Calcium & 18 & $75 \mathrm{mg} / \mathrm{l}$ \\
\hline 9 & Magnesium & 11.3 & $30 \mathrm{mg} / \mathrm{l}$ \\
\hline 10 & Chloride & 64 & $250 \mathrm{mg} / \mathrm{l}$ \\
\hline 11 & Fluoride & 0.1 & $1 \mathrm{mg} / \mathrm{l}$ \\
\hline 12 & Nitrate & 8 & $45 \mathrm{mg} / \mathrm{l}$ \\
\hline 13 & Residual Chlorine & 0 & $0.2 \mathrm{mg} / 1$ \\
\hline
\end{tabular}

Remarks:

1) Hardness due to Ca \& Mg- 90 to $95 \%$ Removed.

2) Suspended solids- 85 to $90 \%$ Removed.

3) Sulphides and Nitrate- 85 to $90 \%$ Removed.

4) Chloride- 95 to $99 \%$ Removed.

5) Turbidity - Concentrate in optimum range (1 NTU)

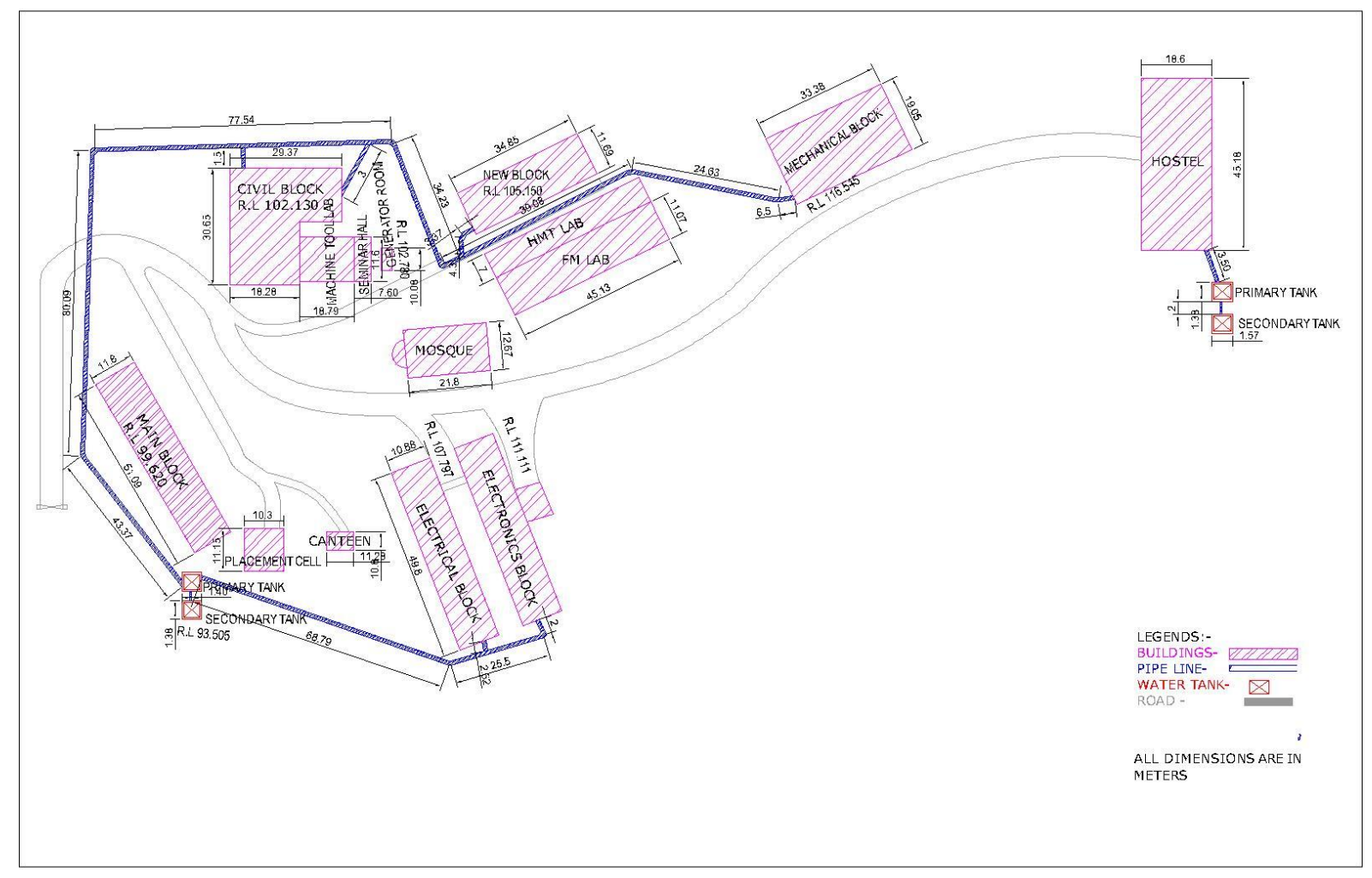

Fig.1. Layout of proposed water tank and pipeline

\section{CONCLUSION}

On the basis of experimental result, it can be concluded that filtration treatment by using Activated Charcoal, Fine sand, Aggregate are successfully executed. This experimental study also found that this filter is more effective for removal of TDS, chloride, hardness due to $\mathrm{Ca}$ and $\mathrm{Mg}$, suspended solids and phenols. The water obtained from the designed filter is very pure and the water is free from impurities, odour, taste, dissolved solids and turbidity. The water has no carbonates and bicarbonates of calcium and magnesium so 
there is no problem of temporary and permanent hardness and the water can be used for laundry purpose. The fact that the water can also be used for cleaning and gardening purpose is an additional advantage. The activated charcoal is available easily, cheap and has high degree of purification. The density and large surface area available for adsorption is an important factor. This process has so many advantages and aimed to meet all the needs of the present situation. Through this study it is conclude that a new source is generated for purpose of irrigation and it reduce the load over potable water demand.

\section{REFERENCES}

[1] A.V. Deshmukh; P.A. Hangarekar; D.C. Paul; "Treatment and reuse of wastewater in COEA campus", International Journal of Engineering and Technology, Volume:04, Issue:08, Aug 2017.

[2] Ishwar P. Patil; Prof. Hemant D. Wagh; Prof. Arun Kumar Dwivedi; "Water recycle and reuse- A case study of NMIMS University campus", International Journal of Engineering Science Invention, Vol:02, Issue:09, Sep 2013

[3] G. Venkatesan; B. Balaji; "Water quality assessment in Tiruchirappalli, India", Asian Journal of Water Environment and Pollution, Vol.10, No. 04

[4] Farid Ansari; Yashwant K Pandey;, "Conceptual design of a waste water treatment plant for industrial estate", Global Journal of Science Frontier Research 2013.

[5] M Arun Pandiyan; A. Anand; "Planning and designing of wastewater treatment plant in Kumbakonam", International Research Journal of Advanced Engineering and Science, 2015

[6] Rakesh Singh Asiwal; Dr. Santhosh Kumar; "Wastewater treatment by effluent treatment plants", International Journal of Civil Engineering Science, 2016. 